\title{
ANTIMICROBIAL EFFECT OF ORGANOTIN COMPOUNDS DERIVED FROM PHENOLIC SCHIFF BASES
}

\section{EFEITO ANTIMICROBIANO DE COMPOSTOS ORGANOESTÂNICOS DERIVADOS DE BASES DE SCHIFF FENÓLICAS}

\author{
A. F. DA S. SANTOS ${ }^{1}$, J. R. DA S. MAIA ${ }^{1 *}$ \\ ${ }^{1}$ Universidade Federal de Viçosa, Departamento de Química, Viçosa, Minas Gerais, Brasil, 36570-901
}

${ }^{*}$ Corresponding author. Universidade Federal de Viçosa, Departamento de Química, Viçosa, Minas Gerais, Brasil, $36570-901$, Phone: +55 31 36126636 e-mail address: jrsmaia@ufv.br(J.R. da S. Maia.).

\begin{tabular}{|c|}
\hline A R T I C L E I N F O \\
\hline $\begin{array}{l}\text { Article history: } \\
\text { Received 2019-09-07 } \\
\text { Accepted 2019-12-20 } \\
\text { Available online 2019-12-20 }\end{array}$ \\
\hline $\begin{array}{l}\text { palavras-chave} \\
\text { Compostos organoestânicos } \\
\text { Caracterização } \\
\text { Efeito antimicrobiano } \\
\text { Bactericidas }\end{array}$ \\
\hline $\begin{array}{l}k e y w o r d s \\
\text { Organotin(IV) compounds } \\
\text { Characterization } \\
\text { Antimicrobial effect } \\
\text { Bactericide }\end{array}$ \\
\hline
\end{tabular}

\begin{abstract}
A B S T R A C T
Several organotin(IV) derivatives of phenolic Schiff bases were prepared and investigated by spectroscopic methods. These compounds were bioassayed to evaluate their bacterial effect against Gram-positive (Staphylococcus aureus and Bacillus subtilis) and Gram-negative (Escherichia coli and Salmonella typhimurium) microorganisms. Dimeric and monomeric compounds were characterized by infrared in solid state. Metallic centers having penta-, hexa, and heptacoordination were identified by multinuclear $N M R\left({ }^{1} \mathrm{H},{ }^{13} \mathrm{C}\right.$ and $\left.{ }^{119} \mathrm{Sn}\right)$ in solution. The di- and triorganotin(IV) derivatives were also investigated by conductimetric measurements in methanol, elemental analysis and melting point. The bioassay of these tin(IV) compounds showed that the best resulting activity was against $S$. aureus for the triphenyltin(IV) phenolic Schiff base derivatives, presenting MICs of $1.1 \mu M\left(0.6 \mu \mathrm{g} \mathrm{mL} L^{-1}\right)$ and $2.2 \mu M\left(1.3 \mu g L^{-1}\right)$.

\begin{tabular}{l} 
R E S U M O \\
\hline Vários derivados organoestânicos de bases de Schiff fenólicas foram preparados e \\
investigados por métodos espectroscópicos. Estes compostosforam avaliados quanto ao efeito \\
bacteriano contra microrganismos Gram-positivos (Staphylococcus aureus e Bacillus \\
subtilis) e Gram-negativos (Escherichia coli e Salmonella typhimurium). Compostos \\
diméricos e monoméricos foram caracterizados por infravermelho no estado sólido. Centros \\
metálicos com penta-, hexa-, e heptacoordenação foram identificados por RMN multinuclear \\
$\left({ }^{1} H,{ }^{13}\right.$ Ce e ${ }^{119}$ Sn) em solução. Os derivados di- e triorganoestânicos foram também analisados \\
por medidas condutimétricas em metanol, análise elementar e ponto de fusão. O bioensaio \\
destes compostos de estanho(IV) mostrou que a melhor atividade resultante foi contra S. \\
aureus para os derivados do trifenilestanho $(I V)$ com as bases de Schiff fenólicas, \\
apresentando MIC de $1,1 \mu M\left(0,6 \mu g \mathrm{~mL}^{-1}\right)$ e $2,2 \mu M\left(1,3 \mu g \mathrm{~mL}^{-1}\right)$.
\end{tabular}
\end{abstract}




\section{INTRODUCTION}

Since the 20's decade organotin compounds are known for being used as antibacterial agents on microorganisms such as Staphylococcus aureus, but it was on the 50's decade that these compounds were used as medicines. For instance, the antibiotic named Stalinon, which has the diethyltin(IV) iodide in its chemical composition, was used for the treatment of lesions caused by Staphylococcus aureus (Barnes e Stoner, 1959).

The usefulness of organotin(IV) compounds have been widespread to other important areas as agroindustry (Poller, 1970). Other biological properties of these compounds are reported as antioxidant, anti-inflammatory, antimalarial and antimicrobial (Wasi et al., 1987; Nath et al., 2006; Beltrán et al., 2007; Abdel Aziz et al., 2012); they have also been tested in vitro as antitumoral drugs demonstrating great efficacy compared to traditional pharmaceutical medicines (Gielen, 1996).

Schiff bases and its organotin(IV) derivatives are acknowledged for presenting antibacterial and antifungal properties (Singh e Singh, 2012). Because of the increasing interest in organotin(IV) compounds as bioactive materials, the synthesis and characterization of tin compounds have been growing in the last decades; especially in association with Schiff bases where an increasing bacterial activity is expected against microorganisms (Nath et al., 2008; Singh and Singh, 2012; Roy et al., 2015).

Continuing our research interest in the field of coordination chemistry associated with the bacterial and antifungal activity of metallic complexes, three Schiff bases and several tri- and diorganotin(IV) derivatives were prepared, characterized, and tested against Gram-positive and Gramnegative bacteria to evaluate their potential as antimicrobial drugs for eventual treatment of human illnesses.

\section{MATERIALS AND METHODS}

Reagents and solvents were purchased from SigmaAldrich, Vetec or FMaia companies and were used without prior purification. The microanalyses were obtained through a Perkin Elmer 200 CHN Elemental Analyser. The molar conductivity of the organotin(IV) compounds was carried out using a Conductivity Jenway Meter 4010 in methanol $\left(10^{-3}\right.$ mol L-1). The infrared spectra of the samples were recorded on a Perkin Elmer FT-IR 1000 through pellets of CsI. The multinuclear NMR $\left({ }^{1} \mathrm{H},{ }^{13} \mathrm{C}\right.$ and $\left.{ }^{119} \mathrm{Sn}\right)$ spectra were recorded on a Bruker Advance DPX-200 MHz and a Varian $300 \mathrm{MHz}$ by means of TMS and $\mathrm{SnMe}_{4}$ as internal references in DMSO-d $\mathrm{d}_{6}$ and $\mathrm{CDCl}_{3}$.

\subsection{Synthesis of the phenolic Schiff Bases}

The synthesis and characterization of the phenolic Schiff bases are reported in previous work by our group; the structures are shown in Figure 1 (Santos et al., 2018). Some typical infrared and NMR data of those ligands are presented herein for comparison to the data of the organotin(IV) derivatives.

(E)-2-((3-hydroxyphenylimino)methyl)phenol: IR (Nujol / CsI, $\left.v_{\text {máx }} / \mathrm{cm}^{-1}\right): 3320 v(\mathrm{OH}) ; 1616 v(\mathrm{C}=\mathrm{N}) .{ }^{1} \mathrm{H}$ NMR (DMSO$\left.\mathrm{d}_{6}, 300 \mathrm{MHz}, \delta\right): 10.24$ (s, C13-OH); 9.67 (s, C1-OH); 8.88 (s, $\mathrm{HC} 7=\mathrm{N}) .{ }^{13} \mathrm{C}$ NMR (DMSO-d $\left.6,75 \mathrm{MHz}, \delta\right): 163.6(\mathrm{C} 13) ; 160.7$
(C7); 158.7 (C1); 149.6 (C5); 133.6 (C11); 133.0 (C9); 130.6 (C3); 119.6 (C10); 119.5 (C8); 116.9 (C12); 114.5 (C4); 112.4 (C2); 108.5 (C6).

(E)-2-((4-hydroxyphenylimino)methyl)phenol: IR (Nujol / CsI, $\left.v_{\text {máx }} / \mathrm{cm}^{-1}\right): 3266 v(\mathrm{OH}) ; 1617 v(\mathrm{C}=\mathrm{N}) .{ }^{1} \mathrm{H}$ NMR (DMSO$\left.\mathrm{d}_{6}, 300 \mathrm{MHz}, \delta\right): 13.44(\mathrm{~s}, \mathrm{C} 13-\mathrm{OH}) ; 9.71(\mathrm{~s}, \mathrm{C} 1-\mathrm{OH}) ; 8.88(\mathrm{~s}$, HC7=N). ${ }^{13} \mathrm{C}$ NMR (DMSO-d 6 , $75 \mathrm{MHz}, \delta$ ): 160.6 (C13); 160.5 (C7); 157.3 (C1); 139.5 (C4); 132.9 (C11); 132.6 (C9); 123.1 (C3, C5); 119.8 (C10); 119.4 (C8); 116.8 (C12); 116.3 (C2, C6).

\section{(E)-2-((hydroxy-2-methylpropan-2-}

ylimino)methyl)phenol: IR (Nujol / CsI, $\left.v_{\text {máx }} / \mathrm{cm}^{-1}\right)$ : $3259 v(\mathrm{OH})$; $1631 v(\mathrm{C}=\mathrm{N}) .{ }^{1} \mathrm{H}$ NMR $\left(\mathrm{CDCl}_{3}, 300 \mathrm{MHz}, \delta\right): 9.87$ (s, C11-OH); $8.32(\mathrm{~s}, \mathrm{HC} 5=\mathrm{N}) ; 3.56\left(\mathrm{~s}, \mathrm{CH}_{2}\right) ; 1.30\left(\mathrm{~s}, \mathrm{C} 2, \mathrm{C} 4,2 \mathrm{CH}_{3}\right) ; 1.16(\mathrm{~s}$, $\mathrm{C} 1-\mathrm{OH}) .{ }^{13} \mathrm{C} \mathrm{NMR}\left(\mathrm{CDCl}_{3}, 75 \mathrm{MHz}, \delta\right): 162.6(\mathrm{C} 11) ; 162.2$ (C5); 132.5 (C9); 131.7 (C7); 118.4 (C6); 118.1 (C8); 117.5 (C10); 70.9 (C1); 60.8 (C3); 23.5 (C2, C4).<smiles>[R]c1cccc(/N=C/c2ccccc2O)c1</smiles><smiles>[R]c1ccc(/N=C/c2ccccc2O)cc1</smiles>

$\mathrm{R}_{2}=\mathrm{OH}$ (E)-2-(((3-hydroxyphenyl)imino)methyl)phenol (3-hmp)

$\mathrm{R}_{1}=\mathrm{OH}$ (E)-2-(((4-hydroxyphenyl)imino)methyl)phenol (4-hmp)<smiles>CC(C)(CO)N=Cc1ccccc1O</smiles>

(E)-2-(((1-hydroxy-2-methylpropan-2-yl)imino)methyl)phenol (hmyp)

Figure 1 - Molecular structures of the phenolic Schiff bases.

\subsection{Synthesis of the Organotin(IV) derivatives}

The tin(IV) derivatives of phenolic Schiff bases were synthesized according to the methodology reported in the literature with slight modifications using triphenyltin(IV) chloride and diphenyltin(IV) dichloride as metal precursors (Sarkar et al., 2011). These tin(IV) derivatives are soluble in usual solvents such as methanol and DMSO and showed to be non-electrolytes in methanol. The general procedure to synthesize these tin(IV) compounds with phenolic Schiff bases is described below:

\subsubsection{Triphenyltin(IV) derivatives}

To a rounded bottom flask of $125 \mathrm{~mL}$, a mixture of 0.365 $\mathrm{g}(0.946 \mathrm{mmol})$ of triphenyltin(IV) chloride and $0.203 \mathrm{~g}(0.952$ $\mathrm{mmol}$ ) of phenolic Schiff base were dissolved in $30 \mathrm{~mL}$ of methanol. The mixture was kept under stirring for $2 \mathrm{~h}$ at room temperature, obtaining an orange solution. Afterwards, the volume of the mixture was removed under reduced pressure leaving an oily material behind which was dissolved in diethyl ether and again removed in a rotary evaporator. This procedure was repeated several times until an orange solid separated within 
the flask. After that the solid was washed with hexane, dried under reduced pressure and kept in desiccators.

$\left[\mathrm{SnPh}_{3}(3-h m p) \mathrm{Cl}\right](\mathbf{1})$ : Color: orange; Yield of $0.533 \mathrm{~g}$ (94\%). Mp ( $\left.{ }^{\circ} \mathrm{C}\right): 99.8$-102.1; Elemental analysis required for $\mathrm{C}_{31} \mathrm{H}_{26} \mathrm{NO}_{2} \mathrm{SnCl}$ : C, 62.19; H, 4.38; N, 2.34. Found: C, 63.47; $\mathrm{H}, 4.52 ; \mathrm{N}, 2.99$. Molar conductivity $(\Omega \mathrm{M}): 0.04 \mathrm{Ohm}^{-1} \mathrm{~mol}^{-1}$ $\mathrm{cm}^{2}$; IR (Nujol/CsI, $\left.v_{\text {máx }} / \mathrm{cm}^{-1}\right): 3138 v(\mathrm{OH}) ; 1646 v(\mathrm{C}=\mathrm{N}) ; 449$ $v(\mathrm{Sn}-\mathrm{N}) ; 336 v(\mathrm{Sn}-\mathrm{Cl}) ;{ }^{1} \mathrm{H}$ NMR (DMSO-d $\left.6,200 \mathrm{MHz}, \delta\right)$ : 13.30 (s, C13-OH); 9.78 (s, C1-OH); 8.94 (s, HC7=N); 8.10 $6.87(\mathrm{Ph}, \mathrm{C}-\mathrm{H}) .{ }^{13} \mathrm{C}$ NMR (DMSO-d $\left.6,50.28 \mathrm{MHz}, \delta\right): 163.1$ (C13); 160.5 (C7); 158.4 (C1); 149.3 (C5); 143.3, 136.0, 132.9, 128.4 (Ph-Sn); (Ph-Sn, C11); 132.6 (C9); 130.2 (C3); 119.2 (C8, $\mathrm{C} 10) ; 116.6$ (C12); 114.2 (C4); 112.0 (C2); 108.3 (C6); ${ }^{119} \mathrm{Sn}$ NMR (DMSO-d 6 , 74.62 MHz, $\delta$ ): -227.0.

$\left[\mathrm{SnPh}_{3}(4-h m p) \mathrm{Cl}\right](2):$ Color: Brown yellow; Yield of $0.489 \mathrm{~g}(87 \%) . \mathrm{Mp}\left({ }^{\circ} \mathrm{C}\right): 128.3$ - 130.9; Elemental analysis required for $\mathrm{C}_{31} \mathrm{H}_{26} \mathrm{NO}_{2} \mathrm{SnCl}$ : C, 62.19; $\mathrm{H}, 4.38 ; \mathrm{N}, 2.34$. Found: C, $65.03 ; \mathrm{H}, 4.80 ; \mathrm{N}, 2.97$. Molar conductivity $(\Omega \mathrm{M}): 0.05 \mathrm{Ohm}^{-}$ $1 \mathrm{~mol}^{-1} \mathrm{~cm}^{2}$; IR (Nujol/CsI, $\left.v_{\text {máx }} / \mathrm{cm}^{-1}\right)$ : $3298 \mathrm{v}(\mathrm{OH}) ; 1647$ $v(\mathrm{C}=\mathrm{N}) ; 448 v(\mathrm{Sn}-\mathrm{N}) ; 335 v(\mathrm{Sn}-\mathrm{Cl}) ;{ }^{1} \mathrm{H}$ NMR $\left(\mathrm{DMSO}^{-} \mathrm{d}_{6}, 200\right.$ $\mathrm{MHz}, \delta): 13.41$ (s, C13-OH); 9.67 (s, C1-OH); $8.90(\mathrm{~s}, \mathrm{HC} 7=\mathrm{N})$; 7.59 - $6.84(\mathrm{Ph}, \mathrm{C}-\mathrm{H}) .{ }^{13} \mathrm{C}$ NMR (DMSO-d $\left.6,50.28 \mathrm{MHz}, \delta\right)$ : 160.5 (C13); 160.4 (C7); 157.3 (C1); 139.4 (C4); 143.3, 136.4 (Ph-Sn); 132.8 (Ph-Sn, C11); 132.5 (C9); 123.0 (Ph-Sn, C3, C5); 119.8 (C10); 119.3 (C8); 116.8 (C12); 116.3 (C2, C6); ${ }^{119} \mathrm{Sn}$ NMR (DMSO-d $6,74.62 \mathrm{MHz}, \delta$ ): -235.5 .

$\left[\mathrm{SnPh}_{3}(\right.$ hmyp $\left.) \mathrm{Cl}\right](3)$ : Color: Dark yellow; Yield of 0.471 g $(78 \%)$. $\mathrm{Mp}\left({ }^{\circ} \mathrm{C}\right): 96.5$ - 98.4. Elemental analysis required for $\mathrm{C}_{29} \mathrm{H}_{30} \mathrm{NO}_{2} \mathrm{SnCl}: \mathrm{C}, 60.19 ; \mathrm{H}, 5.23 ; \mathrm{N}, 2.42$. Found: C, 60.85; $\mathrm{H}, 5.41 ; \mathrm{N}, 2.48$. Molar conductivity $(\Omega \mathrm{M}): 0.04 \mathrm{Ohm}^{-1} \mathrm{~mol}^{-1}$ $\mathrm{cm}^{2}$; IR (Nujol/CsI, $\left.v_{\text {máx }} / \mathrm{cm}^{-1}\right)$ : 3414 v(OH); $1643 v(\mathrm{C}=\mathrm{N}) ; 460$ $v(\mathrm{Sn}-\mathrm{N}) ; 280,284 \mathrm{v}(\mathrm{Sn}-\mathrm{Cl}) ;{ }^{1} \mathrm{H}$ NMR (DMSO-d $\left.6,200 \mathrm{MHz}, \delta\right)$ : $14.44(\mathrm{~s}, \mathrm{C} 11-\mathrm{OH}) ; 8.59(\mathrm{~s}, \mathrm{HC} 5=\mathrm{N}) ; 5.07$ (s, broad, C1-OH) $3.47\left(\mathrm{~s}, \mathrm{CH}_{2}\right) ; 7.97$ - $6.86(\mathrm{Ph}, \mathrm{C}-\mathrm{H}) ; 1.29\left(\mathrm{~s}, 2 \mathrm{CH}_{3}\right) .{ }^{13} \mathrm{C} \mathrm{NMR}$ (DMSO-d $6,50.28 \mathrm{MHz}, \delta): 162.4$ (C11, C5); 144.0, 136.1, 132.2, 128.7 (Ph-Sn); 118.7 (C6); 117.7 (C8); 117.1 (C10); 69.2 (C1); 60.6 (C3); 23.9 (C2, C4); ${ }^{119}$ Sn NMR (DMSO-d $6,74.62$ $\mathrm{MHz}, \delta):-228.9$.

\subsubsection{Diphenyltin(IV) derivatives}

The preparation of the diphenytin(IV) compounds followed the same procedure as the triphenyltin(IV) derivatives.

$\left[\mathrm{SnPh}_{2}(3-h m p) \mathrm{Cl}_{2}\right] \cdot 2 \mathrm{H}_{2} \mathrm{O}$ (4): Color: Gold yellow; Yield of $0.458 \mathrm{~g}(87 \%) . \mathrm{Mp}\left({ }^{\circ} \mathrm{C}\right): 52.3$ - 54.0; Elemental analysis required for $\mathrm{C}_{25} \mathrm{H}_{25} \mathrm{NO}_{4} \mathrm{SnCl}_{2}: \mathrm{C}, 50.63 ; \mathrm{H}, 4.25 ; \mathrm{N}, 2.36$. Found: C, 50.98; H, 3.79; N, 2.40. Molar conductivity $(\Omega M)$ : $0.07 \mathrm{Ohm}^{-1} \mathrm{~mol}^{-1} \mathrm{~cm}^{2}$; IR (Nujol/CsI, $\left.v_{\text {máx }} / \mathrm{cm}^{-1}\right): 3336 \mathrm{v}(\mathrm{OH})$; $1636 v(\mathrm{C}=\mathrm{N}) ; 577 v(\mathrm{Sn}-\mathrm{O}) ; 452 v(\mathrm{Sn}-\mathrm{N}) ; 337 v(\mathrm{Sn}-\mathrm{Cl}) ;{ }^{1} \mathrm{H}$ NMR (DMSO-d 6 , $200 \mathrm{MHz}, \delta): 13.26$ (s, C13-OH); 9.75 (s, C1$\mathrm{OH}) ; 8.91(\mathrm{~s}, \mathrm{HC} 7=\mathrm{N}) ; 7.97-6.85(\mathrm{Ph}, \mathrm{C}-\mathrm{H}) .{ }^{13} \mathrm{C} \mathrm{NMR}$ (DMSO-d $6,50.28 \mathrm{MHz}, \delta$ ): 163.2 (C13); 160.5 (C7); 158.4 (C1); 149.3 (C5); 144.4, 136.2, 129.0 (Ph-Sn); 130.3 (C3); 119.3 (C8, C10); 116.7 (C12); 114.3 (C4); 112.1 (C2); 108.3 (C6). ${ }^{119} \mathrm{Sn}$ NMR (DMSO-d $\left., 74.62 \mathrm{MHz}, \delta\right):-226.3$.

$\left[\mathrm{SnPh}_{2}(4-h m p) \mathrm{Cl}_{2}\right] \cdot \mathrm{H}_{2} \mathrm{O}$ (5): Color: Brown; Yield of $0.424 \mathrm{~g}(80 \%) . \mathrm{Mp}\left({ }^{\circ} \mathrm{C}\right): 71.0$ - 72.1; Elemental analysis required for $\mathrm{C}_{25} \mathrm{H}_{23} \mathrm{NO}_{3} \mathrm{SnCl}_{2}: \mathrm{C}, 52.21 ; \mathrm{H}, 4.03 ; \mathrm{N}, 2.44$. Found: C, 51.50; H, 3.85; N, 2.37. Molar conductivity $(\Omega \mathrm{M})$ : $0.04 \mathrm{Ohm}^{-1} \mathrm{~mol}^{-1} \mathrm{~cm}^{2}$; IR (Nujol/CsI, $\left.v_{\text {máx }} / \mathrm{cm}^{-1}\right): 3330 \mathrm{v}(\mathrm{OH})$; $1634 v(\mathrm{C}=\mathrm{N}) ; 576 v(\mathrm{Sn}-\mathrm{O}) ; 453 v(\mathrm{Sn}-\mathrm{N}) ; 338 v(\mathrm{Sn}-\mathrm{Cl}) ;{ }^{1} \mathrm{H}$
NMR (DMSO-d 6,200 MHz, $\delta$ ): 10.99 (s, C13-OH); 8.49 (s, C1$\mathrm{OH}) ; 7.97(\mathrm{~s}, \mathrm{HC} 7=\mathrm{N}) ; 7.33-6.54(\mathrm{Ph}, \mathrm{C}-\mathrm{H}), 4.29\left(\mathrm{H}_{2} \mathrm{O}\right) .{ }^{13} \mathrm{C}$ NMR (DMSO-d $6,50.28 \mathrm{MHz}, \delta$ ): 160.7, (C13); 160.6 (C7); 157.5 (C1); 136.5 (C5); 135.2, 133.6, 128.8, 128.2 (Ph-Sn); 139.6 (C4); 133.0 (C11); 132.6 (C9); 123.1 (C3, C5) 119.9 (C10); 119.4 (C8); 116.9 (C12); 116.4 (C2, C6). ${ }^{119}$ Sn NMR (DMSO-d $6,74.62 \mathrm{MHz}, \delta)$ : -228.9, -404.7, -502.9, -511.3, $520.4,-522.8,-611.3,-618.1,-625.6,-641.9,-669.7$.

$\left[\mathrm{SnPh}_{2}(\right.$ hmyp $\left.) \mathrm{Cl}_{2}\right] \cdot 3 \mathrm{H}_{2} \underline{\mathrm{O}}$ (6): Color: Light yellow; Yield of $0.442 \mathrm{~g}(79 \%)$. $\mathrm{Mp}\left({ }^{\circ} \mathrm{C}\right): 63.2$ - 65.3; Elemental analysis required for $\mathrm{C}_{25} \mathrm{H}_{23} \mathrm{NO}_{3} \mathrm{SnCl}_{2}$ : C, 46.73; H, 5.29; N, 2.37. Found: C, 45.97; H, 4.95; N, 2.74. Molar conductivity $(\Omega \mathrm{M})$ : $0.06 \mathrm{Ohm}^{-1} \mathrm{~mol}^{-1} \mathrm{~cm}^{2}$; IR (Nujol/CsI, $\left.v_{\text {máx }} / \mathrm{cm}^{-1}\right): 3410 v\left(\mathrm{H}_{2} \mathrm{O}\right.$, $\mathrm{OH}) ; 1642 v(\mathrm{C}=\mathrm{N}) ; 575 v(\mathrm{Sn}-\mathrm{O}) ; 452 v(\mathrm{Sn}-\mathrm{N}) ; 330 v(\mathrm{Sn}-\mathrm{Cl})$; ${ }^{1} \mathrm{H}$ NMR (DMSO-d $\left.6,200 \mathrm{MHz}, \delta\right): 10.28$ (s, C11-OH); 8.03 (s, $\mathrm{HC} 5=\mathrm{N}) ; 7.97-6.86(\mathrm{Ph}, \mathrm{C}-\mathrm{H}) ; 5.50$ (s, broad, $\left.\mathrm{C} 1-\mathrm{OH}, \mathrm{H}_{2} \mathrm{O}\right)$ $3.37\left(\mathrm{~s}, \mathrm{CH}_{2}\right) ; 1.19\left(\mathrm{~s}, 2 \mathrm{CH}_{3}\right) .{ }^{13} \mathrm{C}$ NMR (DMSO-d $6,50.28 \mathrm{MHz}$, $\delta): 161.1(\mathrm{C} 11) ; 156.5(\mathrm{C} 5) ; 147.0,136.8,135.2,128.0(\mathrm{Ph}-\mathrm{Sn})$; 122.6 (C6); 119.8 (C8); 117.6 (C10); 66.8 (C1); 54.9 (C3); 22.6 $(\mathrm{C} 2, \mathrm{C} 4) .{ }^{119} \mathrm{Sn}$ NMR (DMSO-d $\left.6,74.62 \mathrm{MHz}, \delta\right):-245.0$; 396.6; -502.4; -540.6; -573.3.

\subsection{Minimum inhibitory concentration (MIC)}

The minimum inhibitory concentration (MIC) was determined by the broth microdilution technique using microplates of 96 wells according to the methodology described in the literature (NCCLS, 2002; 2003; Zacchino e Gupta, 2007). The concentration of the standard solution was $1000 \mu \mathrm{g} \mathrm{mL} \mathrm{m}^{-1}$, which was obtained by dissolving the substance $(1.0 \mathrm{mg})$ to be evaluated in a mixture of DMSO $(250 \mu \mathrm{L})$ with sterile water $(750 \mu \mathrm{L})$.

Aliquots for the bioassay screening were prepared diluting the standard solution to a concentration range of 1.0 to $1720 \mu \mathrm{M}\left(0.6\right.$ to $\left.333.3 \mu \mathrm{g} \mathrm{mL}^{-1}\right)$. Each of the bacteria strain were grown under stirring in $3.0 \mathrm{~mL}$ of Luria Bertani (LB) at $37{ }^{\circ} \mathrm{C}$ until an optical density (OD) between 0.08 and 0.10 being achieved, which is equivalent to 1.0 to $2.0 \times 10^{8} \mathrm{CFU}$ (colonyforming unit) $\mathrm{mL}^{-1}$. Afterwards, $100 \mu \mathrm{L}\left(5.0 \times 10^{4} \mathrm{CFU}\right)$ of $\mathrm{LB}$ from each bacterial strain was added to $50 \mu \mathrm{L}$ containing the substance to be bioassayed.

The resultant mixture was transferred to microplates for incubation throughout $24 \mathrm{~h}$ and they were read to collect information using a spectrometer ELISA at $600 \mathrm{~nm}$. The experiment was carried out in duplicate considering the standard deviation. The DMSO was the negative control, and the Amoxicillin and Norfloxacin were the positive control. The strains of bacteria used in the bioassay of the tin(IV) derivatives of the phenolic Schiff base were Staphylococcus aureus (ATCC33591), Bacillus subtilis (ATCC23858), Escherichia coli (ATCC29214) and Salmonella typhimurium (ATCC14028).

\section{RESULTS AND DISCUSSION}

\subsection{Infrared Spectroscopy}

The stretching vibration of the imine group bonded to the metal center in these tin(IV) derivatives shifted towards high frequency upon coordination. This is evidence for coordination of the nitrogen atom from the phenolic Schiff base to the metal ion. The average shift of the infrared bands from the imine bond of the triphenyltin(IV) derivatives, compounds 1, 2 and 3, was 
around $24 \mathrm{~cm}^{-1}$ which is slightly higher, around $8 \mathrm{~cm}^{-1}$, compared to the diphenyltin(IV) derivatives, compounds $\mathbf{4}, \mathbf{5}$ and 6, which have the average around $16 \mathrm{~cm}^{-1}$. The infrared shift towards high frequency is an indication that the imine bond become stronger by coordination to the metallic center. This effect on the infrared vibrations allow to speculate that the electron donor effect of the hydroxyl group at the ortho position of the phenyl ring affects the electron density on the imine bond of the ligand upon coordination. The higher average might correlates to monodentate coordination and the lesser average to the chelating coordination mode through the hydroxyl groups at the ortho position of the phenol ring for the tri- and diphenyltin(IV) derivatives respectively.

The observable infrared shifts of the hydroxyl groups in these tin(IV) derivatives can be correlated to intermolecular hydrogen bonds, because of lattice water, with new bonds from the ligands to the metal or both. The infrared shift of the coordinated hydroxyl groups is a difficult task to assign because their vibrational modes shifted slightly in comparison with the free ligands.

New vibrational bands in the region of $448 \mathrm{~cm}^{-1}$ were revealed for the triphenyltin(IV) compounds, $\mathbf{1}$ and $\mathbf{2}$, and another band at $460 \mathrm{~cm}^{-1}$ for the compound 3 (Nakamoto, 1997; Chandra e Sharma, 2009). These infrared absorptions are correlated to the vibrational stretching mode of the metalnitrogen bond. Medium to strong bands in the region of $335 \mathrm{~cm}^{-}$ ${ }^{1}$ were also revealed for the compounds $\mathbf{1}$ and $\mathbf{2}$, and two weak bands in the region of $282 \mathrm{~cm}^{-1}$ for the compound 3 . These vibrational bands are related to the formation of the metalchlorine bonds.

The infrared data for the metal-imine bonds indicate that the phenolic Schiff bases are bonded to the metallic center, in the compounds $\mathbf{1}, \mathbf{2}$ and $\mathbf{3}$, by a monodentate mode in a trigonal bipyramidal structure in solid state. Nevertheless, the infrared data for the metal-chlorine bonds in compound $\mathbf{3}$ indicates a dimeric structure with chlorine atoms in a bridged bidentate mode (Santos et al., 2018). Possible structural arrangements in solid state are showed in Figure 2.
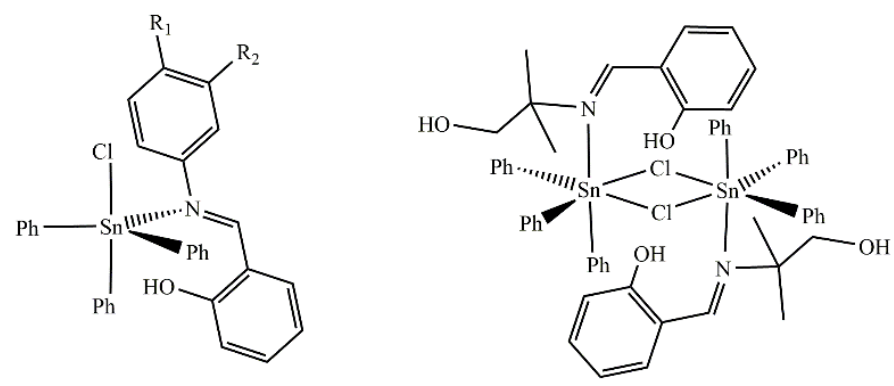

$\mathrm{R}_{2}=\mathrm{OH}, \mathrm{R}_{1}=\mathrm{H}(3-h m p)$ (1)

$\mathrm{R}_{1}=\mathrm{OH}, \mathrm{R}_{2}=\mathrm{H}(4-h m p)(\mathbf{2})$

(hmyp) (3)

\section{Figure 2 - Possible structures of the triphenyltin(IV) derivatives in solid state.}

New bands in the region of $576 \mathrm{~cm}^{-1}$ were assigned to the tin(IV)-oxygen bonds for the diphenyltin(IV) derivatives, the compounds 4, 5 and 6 (Nakamoto, 1997). The metal-nitrogen and chloride bonds were identified in the region of $452 \mathrm{~cm}^{-1}$ and $335 \mathrm{~cm}^{-1}$ respectively (Nakamoto, 1997). In the solid state, the unique band of the coordinated chlorine atoms put them in trans position to the metal ion at the axial position of an octahedron. This geometrical structure is corroborated by the infrared data relative to the metal-oxygen and metal-nitrogen bonds where the phenolic Schiff bases are bonded in a bidentate coordination mode to the diphenyltin(IV) moiety.

The vibrational energy between the metal-nitrogen and metal-oxygen bonds for these three compounds are close which suggests that all have followed the same structural pattern upon coordination by a chelating coordination mode. Possible arrangements in solid state are showed in Figure 3.
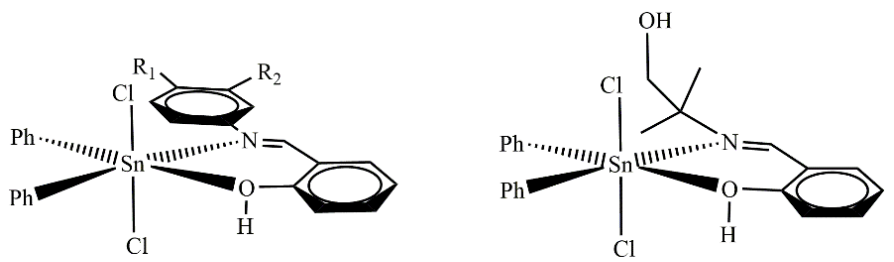

$\mathrm{R}_{2}=\mathrm{OH}, \mathrm{R}_{1}=\mathrm{H}(3-h m p)$ (4)

$\mathrm{R}_{1}=\mathrm{OH}, \mathrm{R}_{2}=\mathrm{H}(4-h m p)(\mathbf{5})$

$($ hmyp $)(\mathbf{6})$

\section{Figure 3 - Possible structures of the diphenyltin(IV)} derivatives in solid state.

\subsection{Multinuclear NMR}

The NMR data showed distinct structural arrangements for the triphenyltin(IV) derivatives in solution when compared with the proposed structures in solid state. All the organotin(IV) derivatives were non electrolytes in solution.

The two hydroxyl groups $(\mathrm{C} 13-\mathrm{OH}, \mathrm{C} 1-\mathrm{OH})$ of compound 1, and the hydrogen atom of the imine moiety revealed a downfield chemical shift by ${ }^{1} \mathrm{H}$ NMR, but the $\mathrm{C} 1-\mathrm{OH}$ and $\mathrm{HC} 7=\mathrm{N}$ groups did not shift significantly. The chemical shift associated with the hydroxyl group of $\mathrm{C} 13-\mathrm{OH}$ was $\delta 3.06$, suggesting a strong interaction with the tin(IV) ion in solution. This chemical shift effect supports that the ligand 3-hmp is bonded to the metal ion on compound $\mathbf{1}$ in a bidentate coordination mode.

The chlorine atoms are acknowledged as labile substituent on organic chemistry. In principle, the coordination of a hydroxyl group to the metal would replace the chloride ion releasing it into the solution because of its lability property. However, the conductivity measurements revealed that these triphenyltin(IV) derivatives are non-electrolytes in methanol (Geary, 1971). Although the ${ }^{13} \mathrm{C}$ NMR chemical shift for this compound is not significant, the ${ }^{119} \mathrm{Sn}$ NMR signal at $\delta-227.0$ corroborates with the formation of a hexacoordinate metallic center in solution as showed on Figure 4 (Das et al., 1987).

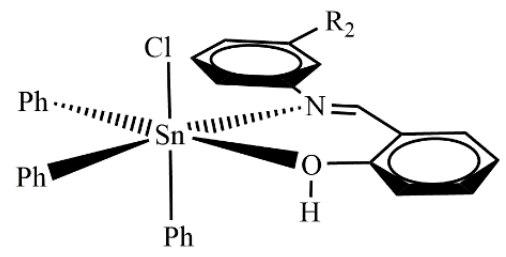

$$
\mathrm{R}_{2}=\mathrm{OH}(3-h m p)(\mathbf{1})
$$

\section{Figure 4 - proposed structure of compound 1 in solution.}

The ${ }^{1} \mathrm{H}$ and ${ }^{13} \mathrm{C}$ NMR of compound 2 did not show considerable chemical shift upon coordination. This data corroborates with the proposed trigonal bipyramidal arrangement of compound $\mathbf{2}$ in solid state, which is retained in solution, as showed on Figure 2. 
The ${ }^{1} \mathrm{H}$ NMR chemical shift of the $\mathrm{C} 11-\mathrm{OH}$ group from compound 3 has shifted $\delta 4.57$ downfield in comparison with the free hmyp. The $\mathrm{C} 1-\mathrm{OH}$ moiety of this compound has also showed a slight broad signal at $\delta 5.07$ which is shifted of $\delta 3.9$ downfield in comparison with the free ligand. Similarly, the carbon atom of the $\mathrm{HC} 5=\mathrm{N}$ group is shifted downfield of $\delta 0.27$. Although the broadness of the signal at $\delta 5.07$ may be correlated to hydrogen bond formation (Tavman et al., 2010), the chemical shift observed for these hydroxyl groups in compound $\mathbf{3}$ is an indication that all are bonded to the metallic center; the coordination to the metallic center comprise monodentate and bidentate modes.

The coordination of the $\mathrm{C} 1-\mathrm{OH}$ might involve a dynamic chemical equilibrium where both hydroxyl groups are bonded to the metal, exchanging between themselves the coordination sphere of the metallic center. Therefore, it is conceivable that the dimeric specie of compound $\mathbf{3}$ in solid state has converted into monomeric arrangements in solution as showed in Figure 5.

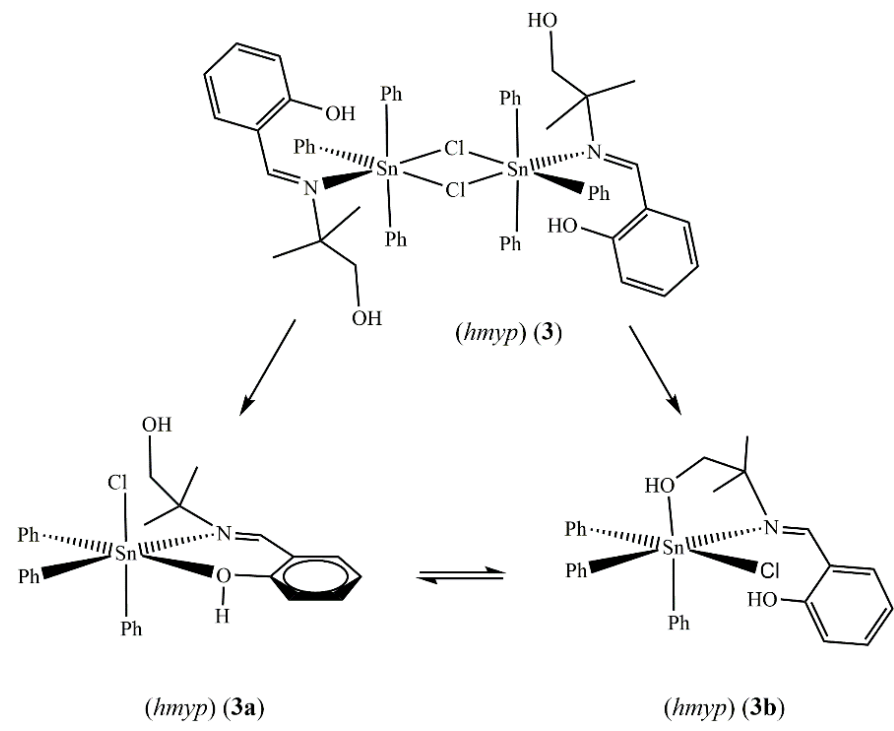

Figure 5 - Proposed structures of compound 3 in solution.

The ${ }^{13} \mathrm{C}$ NMR of compound $\mathbf{3}$ did not show a significant chemical shift for the $\mathrm{C} 11-\mathrm{OH}$ group, although the carbon atom of the C1-OH group shifted $\delta 1.70$ upfield. Nevertheless, the ${ }^{119} \mathrm{Sn}$ NMR data corroborates for the existence of hexacoordinate monomers in solution by the unique signal at $\delta$ -228.9 (Das et al., 1987). Although the hydroxyl groups are acknowledged as weak ligands, crystalographic studies of Zn(II) derivatives of phenolic Schif bases revealed that they make stable bonds to metal ions (Santos et al., 2018).

The ${ }^{1} \mathrm{H}$ NMR of compound 4 showed a downfield chemical shift of $\delta 3.02$ for the $\mathrm{C} 13-\mathrm{OH}$ group, reinforcing a strong interaction of it with the metal ion. The $\mathrm{C} 1-\mathrm{OH}$ and $\mathrm{HC} 7=\mathrm{N}$ groups did not shift significantly. This chemical shift, beyond the coordination of the ligand, can also be ascribed to intermolecular interactions in solution. No significant chemical shift for these groups, however, has occurred in the ${ }^{13} \mathrm{C}$ NMR. The spectroscopic data of compound $\mathbf{4}$ reinforces that the proposed structure in Figure 3 is retained in solution where the 3-hmp is coordinated to the metallic center by a bidentate coordination mode. The ${ }^{119} \mathrm{Sn}$ NMR confirms an octahedral geometry for this compound by the unique signal at $\delta-226.3$ (Das et al., 1987; Deák et al., 2000).
The ${ }^{1} \mathrm{H}$ NMR of compound $\mathbf{5}$ showed a slightly different spectral pattern. The hydrogen signals of the groups $\mathrm{C} 13-\mathrm{OH}$, $\mathrm{C} 1-\mathrm{OH}$ and $\mathrm{HC} 7=\mathrm{N}$ shifted upfield of $\delta 2.45,1.22$ and 0.91 respectively. The ${ }^{13} \mathrm{C}$ NMR chemical shifts of these groups were not significant, but several signals of ${ }^{119} \mathrm{Sn}$ NMR were observed in the range of $\delta-228.9$ to -669.7 . These range of resonance signals are acknowledged to hexacoordinated and heptacoordinated metallic centers of tin compounds (Dubey e Singh, 2013; Chans et al., 2015). In this case it is reasonable to conclude that compound $\mathbf{5}$ is a mixture of monomeric species with the metal centers having both coordination patterns in solution, and even dimeric compounds with the metallic center having distinct coordination centers. The stereochemistry of 4hmp in this compound suggests a bridging coordination mode for this ligand where the $\mathrm{C} 1-\mathrm{OH}$ group makes a bond to a second metallic center to complete its heptacoordination.

The ${ }^{1} \mathrm{H}$ NMR of compound $\mathbf{6}$ showed a downfield chemical shift for both $\mathrm{C} 11-\mathrm{OH}$ and $\mathrm{C} 1-\mathrm{OH}$ groups, but an upfield shift of $\delta 0.29$ for the HC5=N moiety. A broad signal at $\delta 5.50$, assigned to the $\mathrm{C} 1-\mathrm{OH}$ group, was also observed for this compound which is slightly downfield in comparison to the signal at $\delta 5.07$ for the same group in compound $\mathbf{3}$; both complexes are hmyp derivatives. The chemical shift for this broad signal is evidence of coordination of the $\mathrm{C} 1-\mathrm{OH}$ group to the metallic center, and hydrogen bond formation with water molecules in solution (Tavman et al., 2010).

The ${ }^{13} \mathrm{C}$ NMR of compound $\mathbf{6}$ did not show relevant chemical shifts. However, the ${ }^{119} \mathrm{Sn}$ NMR showed signals in the range of $\delta-240$ to -580 revealing that compound $\mathbf{6}$ is also a mixture of monomeric species with the metal ion at the center of an octahedral geometry as well as in a pentagonal bipyramidal geometry, probably in a dynamic equilibrium as showed in Figure 6 (Dubey e Singh, 2013; Chans et al., 2015).

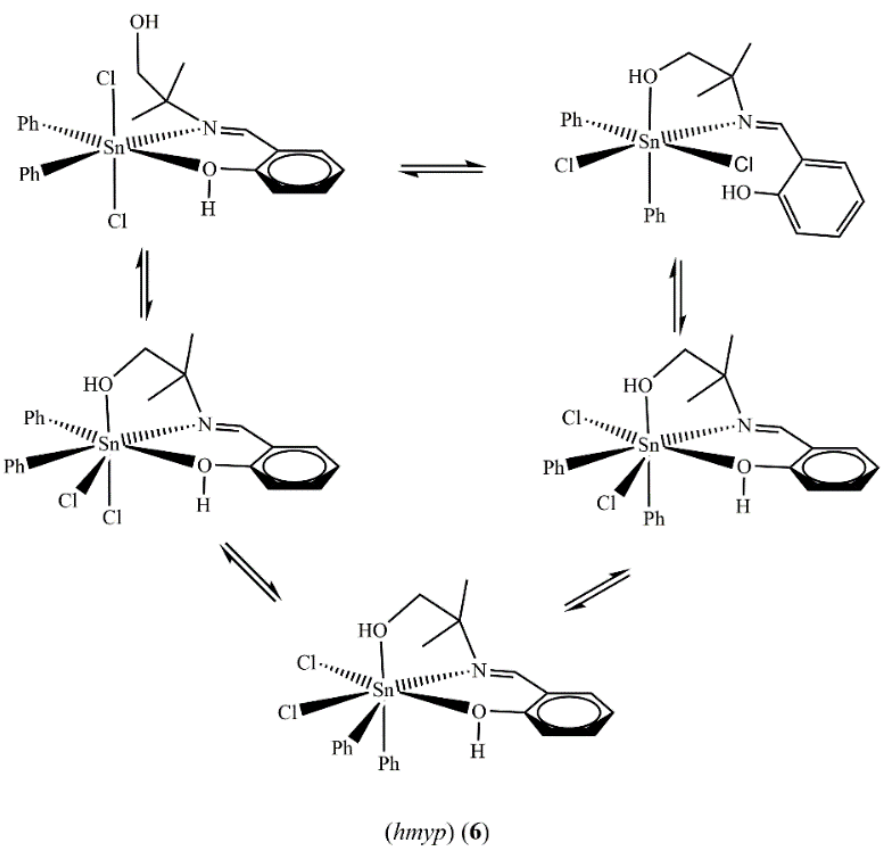

Figure 6 - Proposed isomers of compound 6 in solution.

\subsection{Antimicrobial Effect}

The compounds of tin(IV) derived from phenolic Schiff bases were bioassayed on strains of Gram-positive (Staphylococcus aureus and Bacillus subtilis) and Gramnegative (Escherichia coli and Salmonella typhimurium) 
microorganisms. The ligand $3-h m p$ is inactive against all the microorganisms; the 4-hmp was active on $S$. aureus and $B$. subtilis, and the hmyp on E. coli only as showed in Table 1.

The metal derivatives presented better activity on the Gram-positive microorganisms compared to the Gram-negative. The compounds 2, 5, Amoxicillin and 4-hmp were inactive on the Gram-negative microorganisms, E. coli and S. typhimurium. The bioactivity of these materials seems to be intrinsically related to several aspects as structural features of these compounds, the synergistic effect between the ligand and the metal ion, and the double cell wall of the Gram-negative microorganisms (Abdallah et al., 2009)

Table 1. Bacterial data (MIC)* of the phenolic Schiff bases, and the tin derivatives

\begin{tabular}{|c|c|c|c|c|}
\hline Compound & $\begin{array}{l}\text { Staphylococcus aureus } \\
\text { (ATCC33591) }\end{array}$ & $\begin{array}{l}\text { Bacillus subtilis } \\
\text { (ATCC23858) }\end{array}$ & $\begin{array}{l}\text { Escherichia coli } \\
\text { (ATCC29214) }\end{array}$ & $\begin{array}{c}\text { Salmonella typhimurium } \\
\text { (ATCC14028) }\end{array}$ \\
\hline 3-hmp & $n a$ & $n a$ & $n a$ & $n a$ \\
\hline 4-hmp & $195.5(41.6)$ & $391.1(83.3)$ & $n a$ & $n a$ \\
\hline hmyp & na & na & $1726.1(333.3)$ & na \\
\hline$\left[\mathrm{SnPh}_{3}(3-h m p) \mathrm{Cl}\right](\mathbf{1})$ & $1.1(0.6)$ & $8.6(5.2)$ & $139.1(83.3)$ & $278.2(166.6)$ \\
\hline$\left[\mathrm{SnPh}_{3}(4-h m p) \mathrm{Cl}\right](\mathbf{2})$ & $208.7(41.6)$ & $208.7(41.6)$ & na & na \\
\hline$\left[\mathrm{SnPh}_{3}(h m y p) \mathrm{Cl}\right](\mathbf{3})$ & $2.2(1.3)$ & $17.9(10.4)$ & $287.8(166.6)$ & $575.9(333.3)$ \\
\hline$\left[\mathrm{SnPh}_{2}(3-h m p) \mathrm{Cl}_{2}\right] \cdot 2 \mathrm{H}_{2} \mathrm{O}(\mathbf{4})$ & $35.1(20.8)$ & $140.4(83.3)$ & $561.9(333.3)$ & $561.9(333.3)$ \\
\hline$\left[\mathrm{SnPh}_{2}(4-h m p) \mathrm{Cl}_{2}\right] \cdot \mathrm{H}_{2} \mathrm{O}(\mathbf{5})$ & $72.3(41.6)$ & $144.8(83.3)$ & na & $n a$ \\
\hline$\left[\mathrm{SnPh}_{2}(\right.$ hmyp $\left.) \mathrm{Cl}_{2}\right] \cdot 3 \mathrm{H}_{2} \mathrm{O}(\mathbf{6})$ & $70.3(41.6)$ & $70.3(41.6)$ & $281.8(166.6)$ & $563.8(333.3)$ \\
\hline Amoxicillin & $14.2(5.2)$ & $>0.4(>0.2)$ & $n a$ & na \\
\hline Norfloxacin & $16.2(5.2)$ & $4.1(1.3)$ & $1.9(0.6)$ & $4.1(1.3)$ \\
\hline
\end{tabular}

Note: *Minimum Inhibitory Concentration - $\mu \mathrm{M}\left(\mu \mathrm{g} \mathrm{mL} \mathrm{m}^{-1}\right) ; n a$ - compound inactive at the highest concentration used in the experiment; DMSO was the negative control; Amoxicillin and Norfloxacin were the positive controls

Among the triphenyltin(IV) derivatives, compound $\mathbf{1}$ and 3 showed better bioassay data on S. aureus and B. subtilis compared to compound 2 . In view of the structural features revealed by the NMR data, the octahedral geometry of the former two compounds with the ligands bidentate to the metal appears to increase the synergistic effect in comparison to the trigonal bipyramidal structure of compound $\mathbf{2}$ in which the ligand is coordinated in a monodentate mode to the metallic center.

The synergistic effect between the metal and the ligand may affects the lipophilicity of these coordination compounds allowing them to get across the lipid membrane of the microorganisms more easily. This property is acknowledged on metal complexes having chelating agents (Alaghaz et al., 2015; $\mathrm{Hu}$ et al., 2016). The best bioassay results were for complexes 1 and 3 on $S$ aureus with MICs of $1.1 \mu \mathrm{M}\left(0.6 \mu \mathrm{g} \mathrm{mL}^{-1}\right)$ and 2.2 $\mu \mathrm{M}\left(1.3 \mu \mathrm{g} \mathrm{mL}^{-1}\right)$ respectively.

The diphenyltin(IV) derivative, compound $\mathbf{4}$, has an octahedral geometry with the ligand bonded in a bidentate mode to the metallic center. The compounds $\mathbf{5}$ and $\mathbf{6}$ are a mixture of monomeric and dimeric species having both an octahedral geometry as well as a bipyramidal pentagonal geometry with the phenolic Schiff bases bonded in bridging, bidentate and tridentate modes. These three diphenyltin(IV) derivatives showed activity on the Gram-negative and Gram-positive microorganisms. The combined mixture of species, compound 5 and 6, seem to reduce the activity in general. The best bioassay result among the diphenyltin(IV) derivatives was on $S$. aureus for compound 4 with MIC of $35.1 \mu \mathrm{M}\left(20.8 \mu \mathrm{g} \mathrm{mL}^{-1}\right)$.

The bioassay data shows that the triphenyltin(IV) derivatives were more active compared to the diphenyltin(IV) compounds. Although the compounds 1, 3 and $\mathbf{4}$ have the same geometric pattern in solution, the resulting bioassay data let to speculate that the synergistic effect is enhanced in the former two by the less acid character of the metal precursor, providing better MIC on S. aureus in comparison to the commercial drugs Amoxicillin and Norfloxacin.

\section{CONCLUSION}

The tin compounds derivatives of the phenolic Schiff bases showed distinct chemical structures on solid state as well as in solution. Among the tin compounds prepared, the triphenyltin(IV) derivatives presented the best bioassay results on $S$. aureus which was even better than the commercial drugs Amoxicillin and Norfloxacin. Although not all the compounds tested showed enhanced results in comparison with the commercial drugs, they can eventually be useful medicines in renewed formulations for the treatment of illnesses associated with the microorganisms tested, especially in diseases caused by S. aureus.

\section{ACKNOWLEDGEMENTS}

This study was financed in part by the Coordenação de Aperfeiçoamento de Pessoal de Nível Superior - Brasil (CAPES) - Finance Code 001. The authors are also grateful to the Brazilian Agencies FAPEMIG and $\mathrm{CNPq}$ for financial support.

\section{REFERENCES}

ABDALLAH, S. M. et al. Spectroscopic study of molecular structures of novel Schiff base derived from ophthaldehyde and 2-aminophenol and its coordination compounds together with their biological activity. Spectrochimica Acta Part A: Molecular and Biomolecular Spectroscopy, v. 73, n. 5, p. 833-840, 2009. ISSN 1386-1425. Available at: 
http://www.sciencedirect.com/science/article/pii/S1386 142509001620 .

ABDEL AZIZ, A. A. et al. Synthesis, structural characterization, thermal studies, catalytic efficiency and antimicrobial activity of some M(II) complexes with ONO tridentate Schiff base N-salicylidene-oaminophenol (saphH2). Journal of Molecular Structure, v. 1010, p. 130-138, 2012/02/29/ 2012. ISSN 0022-2860. Available at: http://www.sciencedirect.com/science/article/pii/S0022 286011009264.

ALAGHAZ, A.-N. M. A. et al. Synthesis, spectroscopic identification, thermal, potentiometric and antibacterial activity studies of 4-amino-5-mercapto-S-triazole Schiff's base complexes. Journal of Molecular Structure, v. 1087, p. 60-67, 2015. ISSN 0022-2860. Available https://www.sciencedirect.com/science/article/pii/S0022 28601500054X.

BARNES, J. M.; STONER, H. B. The toxicology of tin compounds. Pharmacological Reviews, v. 11, n. 2, p. 211-231, 1959. ISSN 0031-6997. Available at: Go to ISI://A1959WT75100003.

BELTRÁN, H. I. et al. Synthesis and characterization of diphenyl-tinIV-salicyliden-ortho-aminophenols: Analysis of in vitro antitumor/antioxidant activities and molecular structures. Journal of Inorganic Biochemistry, v. 101, n. 7, p. 1070-1085, 2007/07/01/ 2007. ISSN 0162-0134. Available http://www.sciencedirect.com/science/article/pii/S0162 013407000724.

CHANDRA, S.; SHARMA, A. K. Nickel(II) and copper(II) complexes with Schiff base ligand 2,6-diacetylpyridine bis(carbohydrazone): Synthesis and IR, mass, ${ }^{1} \mathrm{H}$ NMR, electronic and EPR spectral studies. Spectrochimica Acta Part A: Molecular and Biomolecular Spectroscopy, v. 72, n. 4, p. 851-857, 2009. ISSN 13861425. Available

at: http://www.sciencedirect.com/science/article/pii/S1386 142508006707

CHANS, G. M. et al. Synthesis and biological activity of trinuclear seven-coordinated tin(IV) complexes derived from tridentate ligands and trimesic acid. Journal of Coordination Chemistry, v. 68 , n. 20, p. 3741-3758, 2015

DAS, V. G. K. et al. Synthesis, spectroscopic study, and x-ray crystal structure of bis[3-(2-pyridyl)-2-thienyl$\mathrm{C}, \mathrm{N}]$ diphenyltin(IV): the first example of a sixcoordinate tetraorganotin compound. Organometallics, v. 6, n. 1, p. 10-14, 1987/01/01 1987. ISSN 0276-7333. Available at: https://doi.org/10.1021/om00144a003.

DEÁK, A. et al. Synthesis and Structural Characterization of Tin(IV)

$\mathrm{N}$-nitroso-N-phenylhydroxylaminato Complexes: Crystal Structures of $\mathrm{Sn}(\mathrm{O} 2 \mathrm{~N} 2 \mathrm{Ph}) 4$, $\mathrm{Ph}_{2} \mathrm{Sn}\left(\mathrm{O}_{2} \mathrm{~N}_{2} \mathrm{Ph}\right)_{2}$ and $\left[\mathrm{Me}_{2} \mathrm{Sn}\left(\mathrm{O}_{2} \mathrm{~N}_{2} \mathrm{Ph}\right)_{2}\right]_{2}$. European Journal of Inorganic Chemistry, v. 2000, n. 1, p. 127 132, 2000. ISSN 1434-1948. Available at: https://onlinelibrary.wiley.com/doi/abs/10.1002/\%28SI CI\%2910990682\%28200001\%292000\%3A1\%3C127\% 3A\%3AAIDEJIC127\%3E3.0.CO\%3B2-Q.

DUBEY, R. K.; SINGH, A. P. Dimeric and monomeric sixcoordinate tin(IV) complexes: synthesis and spectral (IR,
NMR $\left({ }^{1} \mathrm{H},{ }^{13} \mathrm{C},{ }^{119} \mathrm{Sn}\right)$, TOF-MS, and ESI-MS) studies. Journal of Coordination Chemistry, v. 66, n. 12, p. 2201-2207, 2013. ISSN 00958972. Available at: http://search.ebscohost.com/login.aspx?direct=true \&d= aph\&AN=88960534\&lang=pt-br\&site=ehost-live \&authtype=ip,cookie, uid.

GEARY, W. J. The use of conductivity measurements in organic solvents for the characterisation of coordination compounds. Coordination Chemistry Reviews, v. 7, p. 81-122, 1971.

GIELEN, M. Tin-based antitumour drugs. Coordination Chemistry Reviews, v. 151, p. 41-51, Jun 1996. ISSN 0010-8545. Available at: Go to ISI://WOS:A1996UV86400003.

HU, X. M. et al. Synthesis, crystal structures, and antimicrobial activity of copper(II) and zinc(II) complexes derived from 2-bromo-4-chloro-6-[(2-morpholin-4ylethylimino)methyl]phenol. Russian Journal of Coordination Chemistry, v. 42, n. 6, p. 418-422, June 01 2016. ISSN 1608-3318. Available at:https://doi.org/10.1134/S107032841605002X.

NAKAMOTO, K. Infrared and Raman Spectra of Inorganic and Coordination Compounds Part B: Applications in Coordination, Organometallic, and Bioinorganic Chemistry. 5th. New York: John Wiley \& Sons Inc., 1997. 385 ISBN ISBN 0-471-16392-9.

NATH, M. et al. New triorganotin (IV) derivatives of dipeptides as models for metal-protein interactions: Synthesis, structural characterization and biological studies. Spectrochimica Acta Part A: Molecular and Biomolecular Spectroscopy, v. 63, n. 1, p. 66-75, 2006/01/01/ 2006. ISSN 1386-1425. Available at :http://www.sciencedirect.com/science/article/pii/S1386 142505002131.

NATH, M. et al. New di- and triorganotin(IV) derivatives of tyrosinylphenylalanine as models for metal-protein interactions: Synthesis and structural characterization. Crystal structure of Me2Sn(Tyr-Phe) center dot $\mathrm{MeOH}$. Journal of Organometallic Chemistry, v. 693, n. 15, p. 2541-2550, Jul 2008. Available at: Go to ISI://000257290900012.

NCCLS. Reference Method for Broth Dilution Antifungal Susceptibility Testing of Yeasts. In: (Ed.). NCCLS document M27-A2. Approved Standard - Second Edition. Pennsylvania, USA: Wayne, v.22, 2002. ISBN ISBN 1-56238-469-4.

NCCLS. Method for Dilution Antimicrobial Susceptibility Tests for Bacteria that Grow Aerobically. In: (Ed.). NCCLS document M7-A6. Pennsylvania, USA, 2003. ISBN ISBN 1-56238-486-4.

POLlER, R. C. The Chemistry of Organotin Compounds. New York: Academic Press, 1970.

ROY, M. et al. Synthesis, characterization, crystal structures and in vitro antimicrobial activities of triorganotin(IV) complexes of azo-dicarboxylates. Inorganica Chimica Acta, v. 426, n. 0, p. 89-98, 2015. ISSN 0020-1693. Available at: http://www.sciencedirect.com/science/article/pii/S0020 169314007294.

SANTOS, A. F. D. S. et al. Novel Zinc(II) of phenol Schiff bases: synthesis, characterisation, crystal structure and antimicrobial activity derivatives. The Journal of 
Engineering and Exact Sciences, v. 4, n. 1, p. 00190027, 2018. ISSN ISSN 2527-1075.

SARKAR, B. et al. Potentiality of organotin(IV) compounds in the control of foliar blight disease of wheat (Triticum aestivum) caused by Bipolaris sorokiniana. Archives of Phytopathology and Plant Protection, v. 44, n. 18, p. 1754-1769, Nov 20112011.

SINGH, H. L.; SINGH, J. Synthesis, spectral, 3D molecular modeling and antibacterial studies of dibutyltin (IV) Schiff base complexes derived from substituted isatin and amino acids. Natural Science, v. Vol.04No.03, p. 9, 2012. Available at: //www.scirp.org/journal/PaperInformation.aspx? PaperID=18067.

TAVMAN, A.; BOZ, I.; BIRTEKSÖZ, A. S. Spectral characterization and antimicrobial activity of 2-(5chloro/nitro-1H-benzimidazol-2-yl)-4-bromo/nitrophenols and their zinc(II) complexes. Spectrochimica Acta Part A: Molecular and Biomolecular Spectroscopy, v. 77, n. 1, p. 199-206, 2010. ISSN 13861425 .
http://www.sciencedirect.com/science/article/pii/S1386 142510002593.

WASI, N. et al. Synthesis of metal complexes of antimalarial drugs and in vitro evaluation of their activity against plasmodium falciparum. Inorganica Chimica Acta, v. 135, n. 2, p. 133-137, 1987/02/01/ 1987. ISSN 00201693. Available

at: http://www.sciencedirect.com/science/article/pii/S0020 169300832776.

ZACCHINO, S. A.; GUPTA, M. P. Manual de técnicas in vitro para la deteccíon de compuestos antifúngicos. Corpus Libros Médicos y Científicos, 2007. ISBN 978950-9030-40-4. 